\title{
THE EFFECTS OF SUPERCRITICAL CARBON DIOXIDE ON THE DEGRADATION AND ANTIMICROBIAL PROPERTIES OF PLA BIOCOMPOSITE
}

\author{
HAZLEEN ANUAR ${ }^{1}$, SITI NUR E'ZZATI MOHD APANDI ${ }^{1}$, SITI \\ MUNIRAH SALIMAH ABD RASHID ${ }^{1}$, FATHILAH ALI ${ }^{2}$, YOSE FACHMI \\ BUYS $^{3}$, MOHD ROMAINOR MANSHOR ${ }^{4}$, SABU THOMAS $^{5}$, NUR AIMI \\ MOHD NASIR ${ }^{1}$
}

*Corresponding Author: hazleen@iium.edu.my

(Received: 12 th April 2019; Accepted: 24 th December 2019; Published on-line: 20 ${ }^{\text {th }}$ January 2020)

\begin{abstract}
Biopolymer products that is biodegradable presently attracting an attention from researchers and industry. The biodegradable packaging based on polylactic acid (PLA), durian skin fibre (DSF), epoxidized palm oil (EPO) and incorporated with cinnamon essential oil (CEO) as antimicrobial agent have been developed and showed to be a promising field of research. This paper reported the effects of supercritical carbon dioxide on the degradation and antimicrobial properties of PLA biocomposite films produced via solvent casting. The biocomposites underwent supercritical carbon dioxide $\left(\mathrm{SCCO}_{2}\right)$ treatment at two different conditions under $40{ }^{\circ} \mathrm{C}$ temperature and at $100 \mathrm{bar}$ and 200 bar pressure. Water absorption test showed that the untreated PLA biocomposite absorbed most water as compared to treated PLA biocomposite with $\mathrm{SCCO}_{2}$ at $5.1 \%$. This is due to the hydrophilic nature of the fibre that absorbed water molecules. Soil burial test showed that the treated PLA biocomposite possessed the highest value of weight losses after 80 days with $97.8 \%$. Biocomposite with the presence of CEO demonstrated antimicrobial activity against both gram-positive and gram-negative bacteria. This showed that $\mathrm{SCCO}_{2}$ significantly improved the properties of PLA biocomposite films. The supercritical fluid treatment of PLA biocomposite could be an alternative for active packaging industries to ensure that the packaging product meets the requirement by consumers as well as being an eco-friendly product.
\end{abstract}

ABSTRAK: Produk biopolimer yang biodegradasi pada masa ini menarik perhatian dari penyelidik dan industri. Pembungkusan biodegradasi berasaskan polilaktik asid (PLA), serat kulit durian (DSF), minyak kelapa sawit terepoksi (EPO) dan ditambah dengan 
https://doi.org/10.31436/iiumej.v21i1.1220

minyak pati kayu manis (CEO) sebagai agen antimikrobial telah dibangunkan dan menjadi bidang penyelidikan. Artikel ini melaporkan kesan karbon dioksida superkritikal terhadap sifat-sifat degradasi dan antimikrobik dari filem biokomposit PLA yang dihasilkan melalui pemutus pelarut. Biokomposit telah menjalani rawatan superkritikal karbon dioksida $\left(\mathrm{SCCO}_{2}\right)$ pada dua keadaan yang berbeza di bawah suhu $40{ }^{\circ} \mathrm{C}$ pada 100 bar dan 200 tekanan bar. Ujian penyerapan air menunjukkan bahawa biocomposite PLA yang tidak dirawat menyerap kebanyakan air berbanding komposisi lain dengan 5.1\%. Ini disebabkan sifat hidrofilik serat yang menyerap molekul air. Ujian penanaman dalam tanah menunjukkan bahawa biocomposite PLA yang dirawat mempunyai nilai kehilangan berat tertinggi setelah 80 hari dengan $97.8 \%$. Biokomposit dengan kehadiran CEO menunjukkan aktiviti antimikrobial terhadap bakteria gram-positif dan gram-negatif. Ini menunjukkan bahawa $\mathrm{SCCO}_{2}$ meningkatkan sifat-sifat filem biocomposite PLA. Rawatan cecair superkritikal PLA biocomposite boleh menjadi alternatif bagi industri pembungkusan untuk memastikan produk pembungkusan memenuhi keperluan pengguna serta menjadi produk mesra alam.

KEY WORDS: Polylactic acid, Durian Skin Fibre, Supercritical carbon dioxide, Degradation properties, and Antimicrobial activity.

\section{INTRODUCTION}

Food packaging is a packaging that provides food for carriage, distribution, packing, trade and end-user to fulfil the consumer expectations. Consumer requirements for secure, environment-friendly and high-quality packaging materials have been increased, and therefore the garbage disposal problems are being resolved [1]. Plastics, papers, metals and glasses are some of the main packaging materials; however plastic packaging is typically used in food packaging. Synthetic plastic packaging is crucial to be disposed and can be wasteful due to its compositions and elemental contents [2]. This waste material ends-up being discarded to landfills and the declining availability of land for this purpose [3]. Realizing this situation, many food packaging manufacturer tried to reduce the reliance on synthetic plastics as well as maintain the quality of food. Researchers have found a solution by developed biopolymers that easily degrade within a definite period, compared to nondegradable plastics.

Due to renewability, biodegradability and commercial viability, development of biodegradable materials is interesting in the food packaging sector, since it provides a replacement to the usage of synthetic products [4]. Other than that, production of biopolymer products can be an initiative income in the agriculture industry. PLA is one of the most promising candidates among the renewable source-based products, due to its availability, biocompatibility, excellent tensile strength, good process ability and biodegradability, which are a significant benefit from an environmental perspective. Biodegradable films produced from starch crops are defined as odor-free, flavourless, and neutral as well as non-toxicity [5]. Despite the benefit features, mechanical properties of PLA are unsatisfactory for packaging applications due to brittleness. The reinforced PLA matrix with natural fibre is believed to improve its mechanical performance [6]. Compared to petroleum-based fibre, natural fibres are more environmentally friendly and potentially decrease the environmental problems due to the biodegradable properties. In order to produce biocomposites while preserving the green features, biopolymers must be reinforced with natural fibre [7]. Natural fibres are also composed of low toxicity and cheap resources.

Durian skin fibre (DSF) has excellent features as reinforcement or filler in PLA biopolymer $[4,8,9]$. Durian or, its scientific name, Durio zibethinus Murray can be found 
https://doi.org/10.31436/iiumej.v21i1.1220

in Southeast Asian countries such as Malaysia, Thailand, Indonesia and Philippines. It is also recognised as the 'king of fruits'. About 45-55 wt\% of durian can be considered as waste including skin and seed because only 55-65 wt \% of durian is flesh [9]. To preserve the green environment, the durian skin waste can be used to produce durian skin fibre (DSF). This attempt could help in reducing the environmental pollution by decreasing the number of organic wastes. Besides, the processability of films can be increased with plasticizers that contribute to decreasing the glass transition temperature $\left(\mathrm{T}_{\mathrm{g}}\right)$ and enhance the polymer chain flexibility [10]. This plasticizer also might overcome specimen's brittleness created by high intermolecular forces. Some researchers acknowledge that the natural plasticizers are better, which can be found naturally extracted from animals, vegetable fats and plants oil $[11,12]$. Among the natural plasticizer, epoxidized palm oil (EPO) is a favourable plant oil due to its characteristics like inexpensive, non-toxicity and availability as a renewable agriculture resource.

Nowadays, the safety issues of food are utterly worrisome in the world. Handling food packaging safety is just significant at the consumer level because many of them have contaminated food if not keep properly [13]. Hence, research in active food packaging could play a primary role in food security guarantee, comprehensively permitted with the industrial sector, farmers, producers, wholesalers, retailers, and government as well as consumer groups. Due to the problems highlighted, there is a necessity to produce food packaging with an anti-microbial agent and preventing food contamination. Bacteria and fungi are examples of active microorganisms which may have migrated through direct interaction between food and packaging material or via moisture from inside packaging layer to the food surface [14]. The movement activity of these compounds might interrupt the lifespan and quality of the product. Active packaging materials in the presence of antimicrobial agents like essential oil may be considered as the contemporary advancement of functional packaging. This antimicrobial agent in biocomposite films can avoid almost all bacteria activities that affect the food contamination [15].

The production of essential oil can be exploited as a natural antimicrobials agent and can be used as one of the additives for food [1]. Different types of essential oils show different significance functional group with own antimicrobial properties. The incorporation of essential oil in biocomposite material as secure antimicrobials is expected to be non-harmful for food product and human consumption. Cinnamon has been used as a spice since long time ago. The major component of essential oil extraction is cinnamaldehyde group, a wellknown functional group because of its strong antioxidant and antibacterial activities [16, 17]. The combination of essential oils into viscous biocomposite solvents via solvent casting has some disadvantages mostly due to hydrophobic oil behaviour by EPO and cinnamon essential oil (CEO) which make it difficult to become a homogeneous film. Therefore, supercritical carbon dioxide $\left(\mathrm{SCCO}_{2}\right)$ treatment is introduced in this study as the dispersion agent to employ PLA biocomposite films.

The $\mathrm{SCCO}_{2}$ process can present an effective and beneficial medium for polymer processing. The major benefits of polymer treatment with $\mathrm{SCCO}_{2}$ include processing at low temperatures, allowing a large amount of carbon dioxide $\left(\mathrm{CO}_{2}\right)$ into different kinds of a polymer including synthetic and biopolymer and rapidly complete solvent elimination from the final product [13]. Besides its greener characteristics, $\mathrm{SCCO}_{2}$ is chemically inert, inexpensive, easily purchased, non-flammable and highly pure. $\mathrm{CO}_{2}$ gas is a suitable solvent for non-polar constituents and dissolves in most polymer compounds [18]. In short, $\mathrm{SCCO}_{2}$ offers regulated product quality and safety as well as efficient time and energy management. To the best of the author's knowledge, the study of supercritical carbon dioxide $\left(\mathrm{SCCO}_{2}\right)$ 
https://doi.org/10.31436/iiumej.v21i1.1220

treatment on antimicrobial biodegradable food packaging material has not been investigated. Therefore, in this study, PLA biocomposite was produced through solvent casting. This paper also discusses the effects of $\mathrm{SCCO}_{2}$ on the anti-microbial, water absorption and soil degradation of PLA/DSF biocomposite films.

\section{EXPERIMENTAL}

\subsection{Materials}

PLA in a pallet form was purchased from NatureWorks ${ }^{\circledR}$, China. The grade of PLA used was $4043 \mathrm{D}$ with a density of $0.998 \mathrm{~g} / \mathrm{cm}^{3}$ and glass transition between range $57-61{ }^{\circ} \mathrm{C}$. Chloroform used as a reagent to dissolve the PLA pallet was supplied by Merck, Malaysia. Durian skin waste crops were obtained from a local market at Sri Gombak, Kuala Lumpur, Malaysia. The dried skins were ground using blender and mill crusher before sieving over 100 to $250 \mu \mathrm{m}$ to obtain durian skin fibre (DSF). Epoxidized palm oil (EPO) was obtained from the Advanced Oleochemical Technology Division of the Malaysia Palm Oil Board (MPOB), Bangi. Cinnamon essential oil (CEO) was bought from IT Tech Research (M) Sdn. Bhd. Luria-Bertani agar (LBA) and Luria-Bertani broth (LHB) were purchased from a local supplier and Escherichia coli strains were collected from the International Islamic University Malaysia (IIUM) under Biotechnology Laboratory. Stock cultures of the studied bacteria were grown in LHB at $30{ }^{\circ} \mathrm{C}$ for $24 \mathrm{~h}$ prior to testing.

\subsection{Biocomposite Preparation}

PLA biocomposite film was produced via solution casting method. Before beginning the experiment, all materials used were kept in an oven with temperature $40{ }^{\circ} \mathrm{C}$ for $24 \mathrm{~h}$ to avoid moisture absorption. Then, $50 \mathrm{ml}$ of chloroform liquid was measured and added into the mixture where the ratio between the PLA mixture and chloroform was 1:10 to obtain $0.05 \mathrm{~mm}$ of film sheet thickness. Fig. 1 (a) shows the mixture of PLA and chloroform in the covered beaker. The detailed amount of composition for each sample was shown in Table 1 . The mixture was then mechanically stirred on a hot plate by using a magnetic stirrer until it reached the homogeneous phase. Total weight of each sample was $5.1 \mathrm{~g}$. The solution mixture is poured into the flat surface of a mould in Fig. 1 (b). Samples were dried after left at room temperature for 1 day as in Fig. 1 (c). Dried films were peeled off from the casting surface and stored inside desiccators at $25 \pm 1{ }^{\circ} \mathrm{C}$ until further evaluation.

\subsection{Supercritical Carbon Dioxide ( $\left.\mathrm{SCCO}_{2}\right)$}

The PLA biocomposite film underent supercritical carbon dioxide $\left(\mathrm{SCCO}_{2}\right)$ method for $2 \mathrm{~h}$ at temperature $40{ }^{\circ} \mathrm{C}$ with different pressure at 100 bar (condition 1) and 200 bar (condition 2). The samples were impregnated with $\mathrm{CO}_{2}$ through a supercritical carbon dioxide machine model Waters (TAP SFE Biobotanical system, IPM) at International Institute for Halal Research and Training (INHART), International Islamic University Malaysia. The $\mathrm{SCCO}_{2}$ treatment was carried out into a vessel containing spores in suspensions or film. The $\mathrm{CO}_{2}$ was impregnated into the PLA biocomposite until the desired pressure was obtained. Next, the $\mathrm{CO}_{2}$ vent valve was immediately unlocked to stop extra reactions in the container. The depressurize time depends on the pressure at that condition. 

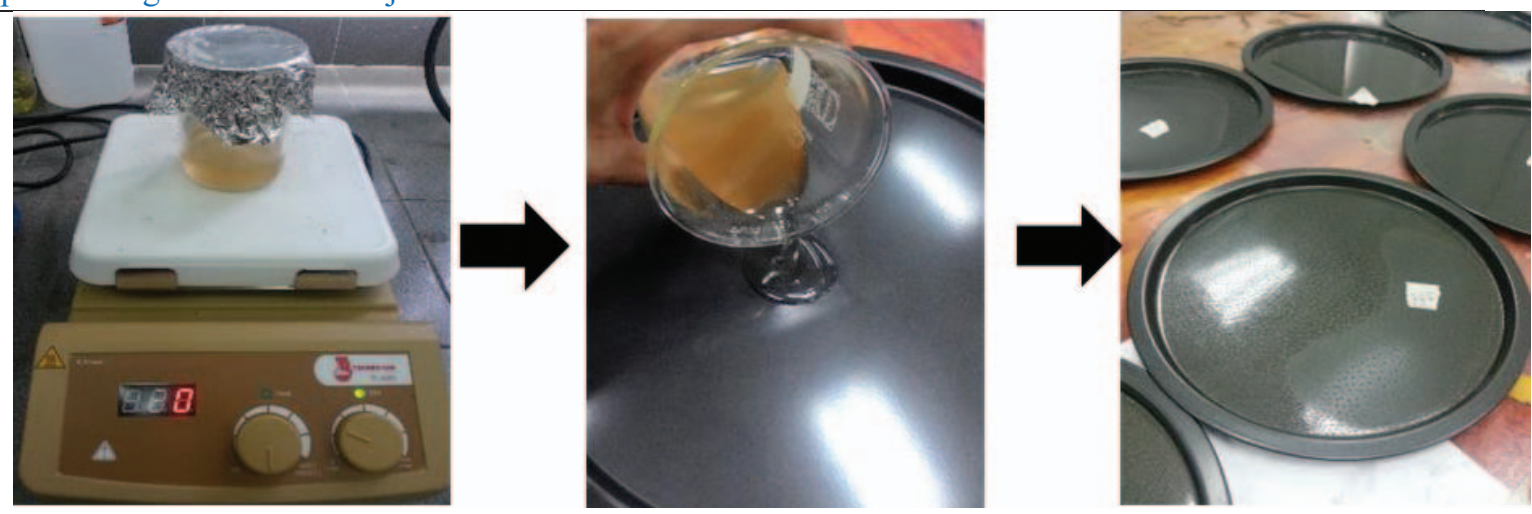

Fig. 1. The PLA biocomposite film preparation via solution casting method a) the mixture was mechanically stirred on a hot plate, $b$ ) poured the sample in mould and

c) samples were dried for $24 \mathrm{~h}$ before peel-off.

Table 1: The composition for each sample

\begin{tabular}{lccccc}
\hline Sample & PLA (g) & DSF (g) & EPO (ml) & CEO (ml) & $\begin{array}{c}\text { Chloroform } \\
(\mathbf{m l})\end{array}$ \\
\hline PLA & $\begin{array}{c}100 \mathrm{wt} \% \\
(5.10)\end{array}$ & - & - & - & 51.00 \\
& $\begin{array}{c}97 \mathrm{wt} \% \\
(4.94)\end{array}$ & $3 \mathrm{wt} \%(0.15)$ & - & - & 51.00 \\
PLA-DSF & $93 \mathrm{wt} \%$ & $3 \mathrm{wt} \%(0.15)$ & $5 \mathrm{wt} \%(0.26)$ & - & 51.00 \\
PLA-DSF-EPO & $(4.68)$ & & & $1 \mathrm{wt} \%$ & \\
& $92 \mathrm{wt} \%$ & $3 \mathrm{wt} \%(0.15)$ & $5 \mathrm{wt} \%(0.26)$ & $(0.05)$ & 51.00 \\
PLA-DSF-EPO- & $(4.68)$ & & & & \\
CEO & & & & & \\
\hline
\end{tabular}

\subsection{Testing Method}

\subsubsection{Water Absorption Analysis}

Water absorption of the films was carried out as per ASTM D570. Before immersed in water, the specimens were dried in an oven for 1 day, placed in a desiccator to get constant weight and subsequently weighted. Each sample was immersed in the distilled water at room temperature until saturated weight was obtained. The weight of the samples was recorded every day for the first 14 days and once a week until the values are equilibrium. The water absorption (\%) was calculated from the difference in weight and stated as the percentage increase of the initial weight as in Eq. (1) [19].

$$
\text { Water absorption }(\%)=\left(\frac{W i-W o}{W o}\right) \times 100
$$

where $W_{i}$ is a weight of the sample after immersion $(\mathrm{g})$ and $W_{o}$ is the initial weight of the sample (g). All data were collected from averaged of five samples tested. Impregnated film at difference condition and non-impregnated specimens were also tested for comparison.

\subsubsection{Soil Burial Degradation Analysis}

Soil burial degradation analysis of PLA biocomposite was measured according to ASTM D5988. The dried thin film specimen of size $5 \mathrm{~cm} \times 5 \mathrm{~cm}$ was prepared. The initial 
https://doi.org/10.31436/iiumej.v21i1.1220

mass of each sample was weighted before buried in soil at a $5 \mathrm{~cm}$ from the soil surface. At these depths, aerobic degradation (action of microorganism) condition could be achieved. The experiment is conducted in an outside laboratory that was exposed to the environment and end for 80 days. The specimens were removed, washed with water, dried in an oven and weighed. The weight losses of the biocomposite sample were studied and recorded based on Eq. (2).

$$
\text { Weight loss }(\%)=\left(\frac{W f-W i}{W i}\right) \times 100
$$

where $W_{i}$ is initial weight of specimen $(\mathrm{g})$ and $W_{f}$ is the final weight of specimen $(\mathrm{g})$. All samples were observed under scanning electron microscope (SEM) before and after soil burial test.

\subsubsection{Antimicrobial Test}

Antimicrobial test used in this project was an inhibition zone test through the agar diffusion method. The sample films prepared beforehand were cut by using sterilized scissors. For this test, the films were cut into $6 \mathrm{~mm}$ diameter and were placed into microcentrifuged tubes. Before place the film into an agar medium, the agar medium was inoculated with $100 \mu \mathrm{L}$ of tested bacteria, S. aureus (positive gram) and E. coli (negative gram). Biocomposite films were then placed on the cultured agar with bacteria. After $24 \mathrm{~h}$ to $36 \mathrm{~h}$, the inhibition zone was remarked upon and measured at three different points by using a ruler to get precise average value.

\subsubsection{Gas Chromatography}

Gas chromatography (GC-TOF/MS) was used to determine the presence of essential oil composition. The interface temperature for GC-MS is $220{ }^{\circ} \mathrm{C}$. The temperature of the ion source is $200^{\circ} \mathrm{C}$ and ionization energy is $70 \mathrm{~V}$. The total ion monitoring (TIC) will be used to detect composition in cinnamon essential oil. Three replicates per each sample were analyzed.

\section{RESULTS AND DISCUSSION}

\subsection{Water Absorption Analysis}

The water absorption test is important in food packaging since water or moisture contributes towards the deterioration of food products. The water absorption curves, which demonstrated the percentage of water uptake of the PLA biocomposites in 30 days, are shown in Fig. 2. Water affected the specimen films, based on the components present in the biocomposite films. It could be observed that the specimens underwent $\mathrm{SCCO}_{2}$ presented lower water absorption in comparison to the untreated specimens. The results showed that the percentage of water absorption slowly increased over the time. Based on Fig. 2, the water uptake for all the specimens slowly increased during the initial days of the experiment and then levelled-off when it reached the equilibrium state. A similar behaviour was reported for the isolated soy protein (SPI) and PLA films, whereby the samples started to sharply swollen in the first minute and then began to slowly shrink due to solubilisation of the samples during the experiment [20]. The films achieved saturated after 18 days, as shown in Fig. 2.

In this present work, the PLA-DSF blend without $\mathrm{SCCO}_{2}$ treatment absorbed the most water $(5.1 \%)$ compared to the other compositions. The water absorption rate increased in the PLA blend when DSF was added. DSF is hydrophilic because it comprises an abundance of hydroxyl groups that tend to attract water molecules [9]. In contrast, PLA is a 
https://doi.org/10.31436/iiumej.v21i1.1220

hydrophobic polymer. The results for the impregnated PLA-DSF sample for conditions 1 and 2 were $4.90 \%$ and $4.83 \%$, respectively. These values corresponded to the formation of micro-porosities observed under SEM in Fig. 4 due to the release of $\mathrm{SCCO}_{2}$ from the polymer. The pressure applied during the $\mathrm{SCCO}_{2}$ treatment significantly influenced the water absorption. Therefore, as the $\mathrm{SCCO}_{2}$ pressure increased, the water uptake decreased. The treated biocomposites under condition 2 at a higher pressure presented lower water absorption for all the samples compared to the biocomposites under condition 1. This behaviour is in agreement with the findings studied by Souza et al. [21] where the cassava starch biocomposite films was impregnated by $\mathrm{SCCO}_{2}$.
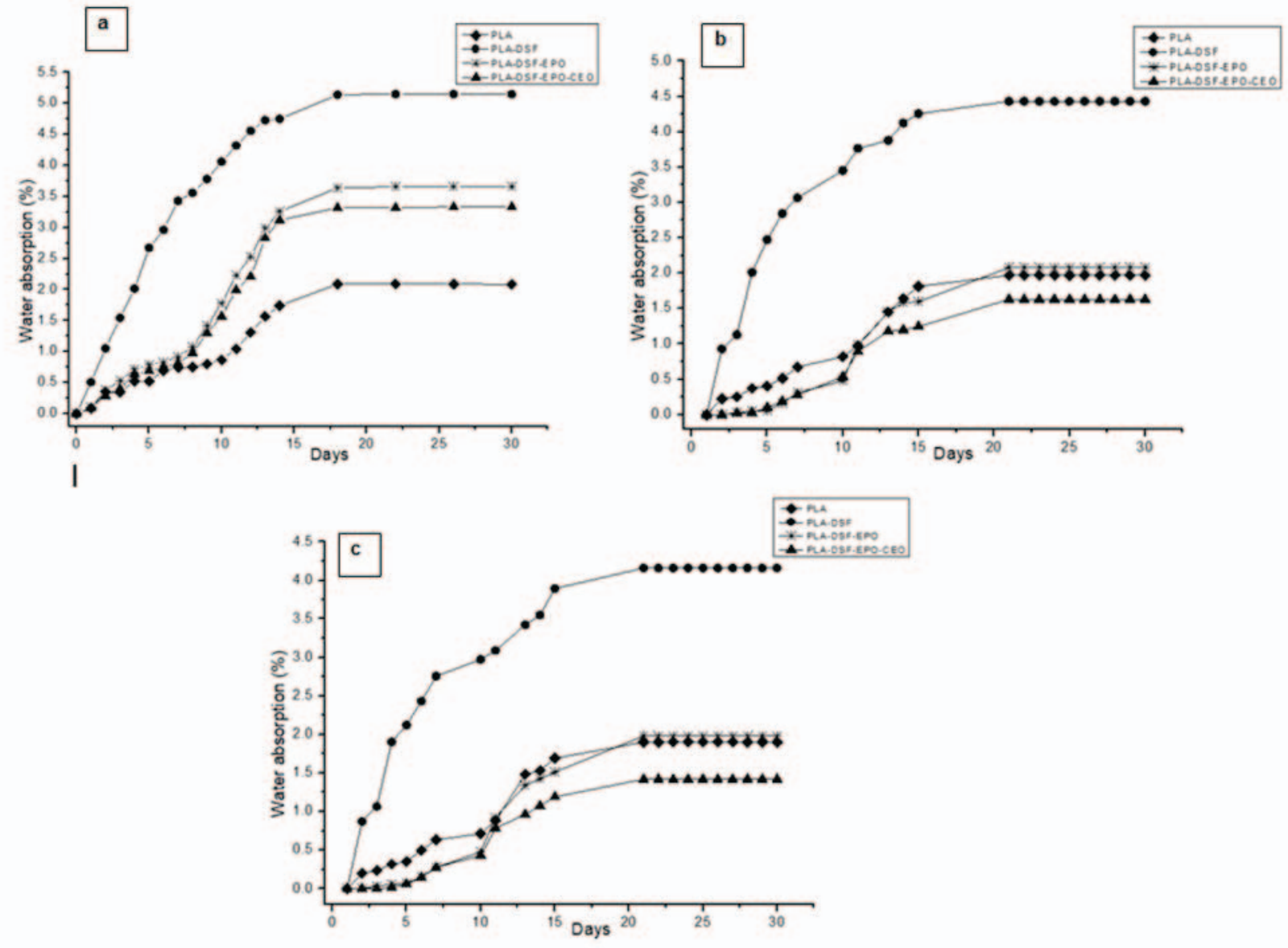

Fig. 2. Water absorption of PLA biocomposite for a) untreated $\mathrm{SCCO}_{2}$, b) treated $\mathrm{SCCO}_{2}$ at condition 1 (100 bar) and c) treated $\mathrm{SCCO}_{2}$ at condition 2 (200 bar).

The addition of hydrophilic fibre into the hydrophobic polymer causing swelling of the matrix [6]. Swelling affects the bonding between the matrix and fibre, thereby, indirectly decreasing the mechanical properties of a biocomposite. The water uptake in the untreated biocomposite after 30 days was $2.09 \%$, while for the treated sample it was $1.96 \%$ (condition 1) and 1.83\% (condition 2). These findings could be due to the hydrophobic nature of the polymer [22]. PLA also possesses good barrier properties against water absorption [20]. Other than that, the presence of EPO in the PLA biocomposite reduced the amount of water absorbed compared to the PLA biocomposite. It was shown that EPO slightly affected the water uptake because EPO functions as a plasticizer and exhibits a hydrophobic nature [23]. Hence, the addition of EPO resulted in a hydrophobic behaviour that tended to resist water molecules. The triglyceride oil compound present in palm oil enables samples to be insoluble in water as reported by Seniha et al. [24]. 
The effect of CEO on water absorption can be observed in Fig. 2. A significant difference was detected in the sample impregnated with CEO, which presented a lower water uptake. After 30 days, an increase of about 3.15\% in the total water uptake of the impregnated film under condition 2 was noted, as depicted in Fig. 2(c), whereas for the film impregnated under condition 1, it was $3.47 \%$, as shown in Fig. 2(b). These results could be correlated to the $\mathrm{SCCO}_{2}$ treatment conditions. As shown in Fig. 2(a), the PLA-DSF-EPO-CEO biocomposite without $\mathrm{SCCO}_{2}$ treatment exhibited a $3.66 \%$ increase, where the water absorption decreased with the addition of CEO. This showed that the presence of CEO in the biocomposite increased its hydrophobicity and subsequently, reduced its ability to absorb water molecules, which is an important improvement for packaging applications.

Nevertheless, the water absorption of the untreated and treated biocomposites varied insignificantly. The water uptake decreased slightly for the sample in the presence of cinnamaldehyde, a compound extracted from pure $\mathrm{CEO}$, as evident in the $\mathrm{GC}$ analysis presented in Fig. 7. The water barrier is a property that dominates potential applications of these plastics in the food industry. Materials with a low ability to absorb water are required to protect food products against contact with water [20, 22].

\subsection{Soil Burial Degradation Analysis}

A soil burial degradation test was used to monitor weight loss of PLA biocomposite sample. Through the soil burial degradation test, the effects of an ordinary and real composting environment on the specimens without any enzymatic and composting resources could be studied. The biodegradability was tested using normal soil to mimic a real environment. The physical appearance was also observed to identify changes in the shape and size of the samples. After 60 days, the samples were observed under SEM. The percentage of weight loss was evaluated using Eq. (2). The weight loss of the untreated and $\mathrm{SCCO}_{2}$-treated PLA biocomposites with different element contents after 80 days of composting are presented in Fig. 3. The weight loss was affected by the absorption of moisture from the soil and the actions of microorganisms [25].

Fig. 3 shows the weight loss of the PLA biocomposite film after 80 days. The results revealed that the percentage of degradation for all the specimens increased with the time interval. The treated PLA biocomposite under condition 2 (200 bar) shows higher degradability with a weight loss of $96.58 \%$, while for the treated PLA biocomposite under condition 1 (100 bar) and the untreated biocomposite the weight loss was $95.17 \%$ and $93.23 \%$, respectively. The treated sample under condition 2 consisted of a more porous structure, which contributed to the increase in the degradation rate of the film. A similar trend had been reported in which the weight loss of the PLA biocomposite increased with the existence of more pores within the blends [3]. Porosity aids bacteria and microorganisms to move through the film as shown in the SEM micrograph in Fig. 5. Additionally, the presence of natural fibre is believed to speed up the degradation of specimens due to poor adhesion between the matrix and reinforcement [6]. Natural fibre is also more compatible with the surrounding environment, which leads to the degradation process. The high cellulose content in the fibre causes high water absorption, which has a synergistic effect on residual loss and improves the degradation rate of composites [5].

The lowest residual loss was exhibited by the unreinforced PLA (65.37\%), while the weight loss of the treated PLA under condition 1 and condition 2 was $67.01 \%$ and $68.56 \%$, respectively. These circumstances occurred due to the hydrophobic behaviour of the PLA, which resulted in a lower water uptake, leading to a reduction in the degradation rate [7]. As such, in the soil burial test, the lower composition of PLA resulted in an increase in the weight loss. However, PLA decomposes better than petroleum-based matrices because of 
https://doi.org/10.31436/iiumej.v21i1.1220

its biodegradability [5]. Biodegradable plastics will eventually degrade in landfills as they are made from natural resources [26]. Other than that, EPO reduced the percentage of weight loss of the PLA biocomposite. Based on Fig. 3, the weight loss for the untreated sample with the added of EPO was $76.72 \%$. In addition, as compared to the untreated biocomposite, the treated biocomposite had an increment of about $2.87 \%$ and $3.56 \%$ in the degradation rate for condition 1 and 2, respectively. EPO acts as a plasticizer to improve the flexibility of PLA biocomposites. Therefore, the porosity of the treated sample increased its degradation rate $[10,23]$.
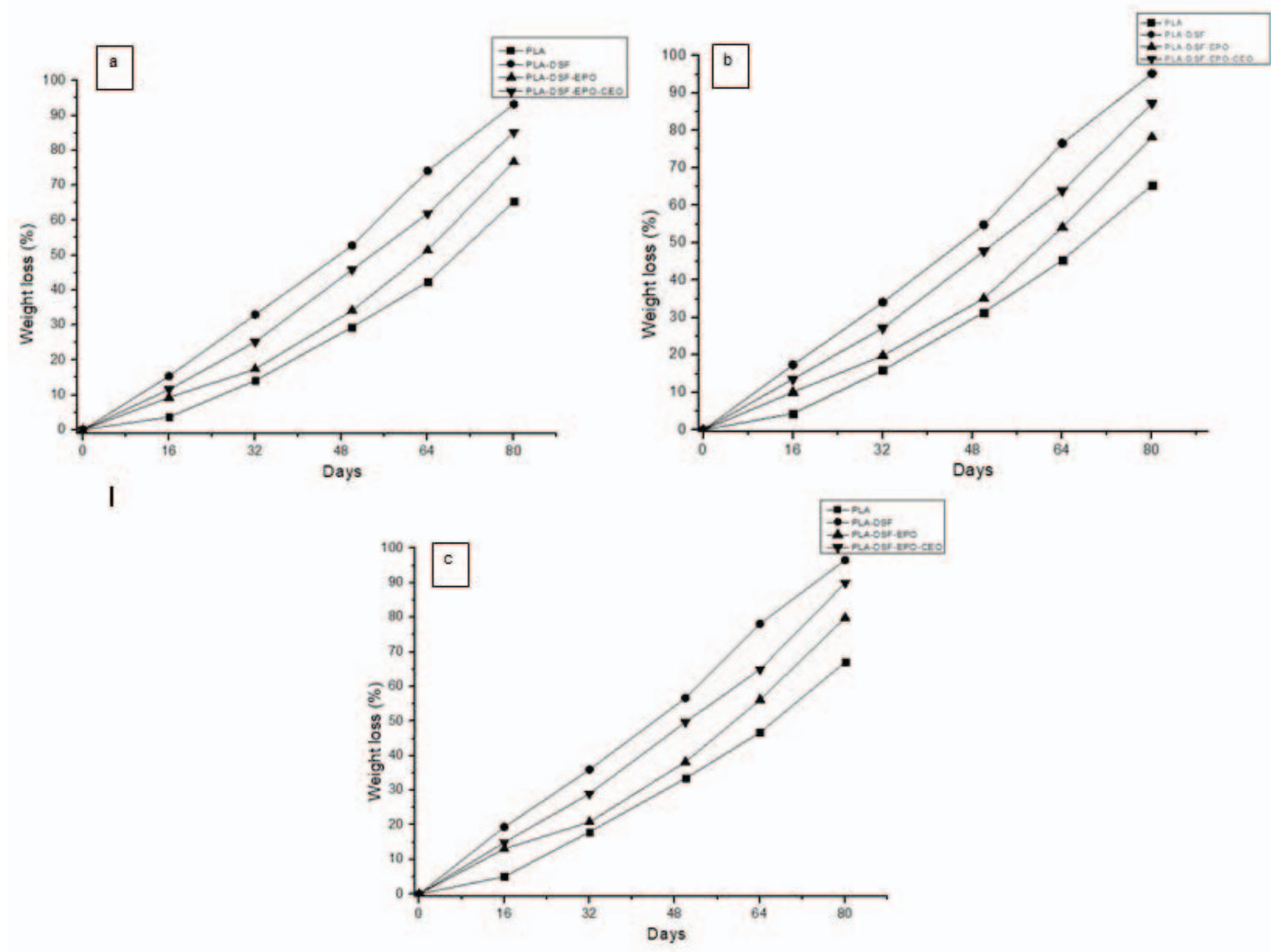

Fig. 3. Weight loss of PLA biocomposite for a) untreated sample, b) treated sample at condition 1 and c) treated sample at condition 2 .

The weight loss experienced by the untreated PLA-DSF-EPO-CEO biocomposite after 80 days was $85.18 \%$ (Fig. 3(a)). This revealed that the degradability of the specimens dependent on the addition of CEO. There was a slight difference between the samples with and without CEO. The PLA biocomposite film with CEO degraded faster in the soil compared to the PLA-DSF-EPO specimen. Fig. 3(c) shows that the treated biocomposite (condition 2) with CEO degraded the fastest, followed by the treated biocomposite (condition 1) and untreated biocomposite. The presence of CEO in the PLA biocomposites weakened the specimens. This caused the degradation rate of the PLA biocomposite films to increase due to the weak bonding after buried in soil. Furthermore, some additive elements inside the specimens might have migrated into the soil and helped in the degradation process [27].

\subsection{Surface Morphology}


https://doi.org/10.31436/iiumej.v21i1.1220

Fig. 4 and 5 illustrate the surface micrographs for the untreated and $\mathrm{SCCO}_{2}$-treated PLADSF-EPO-CEO films before and after 60 days of the soil burial degradation test. This confirmed that various changes had taken place on the surface of the biocomposite films. The results for the sample without $\mathrm{SCCO}_{2}$ treatment are shown in Fig. 4, while the findings for the treated samples under conditions 1 and 2 are presented in Fig. 5. After the degradation process, more pores and visible ruptures on the surface were noted.
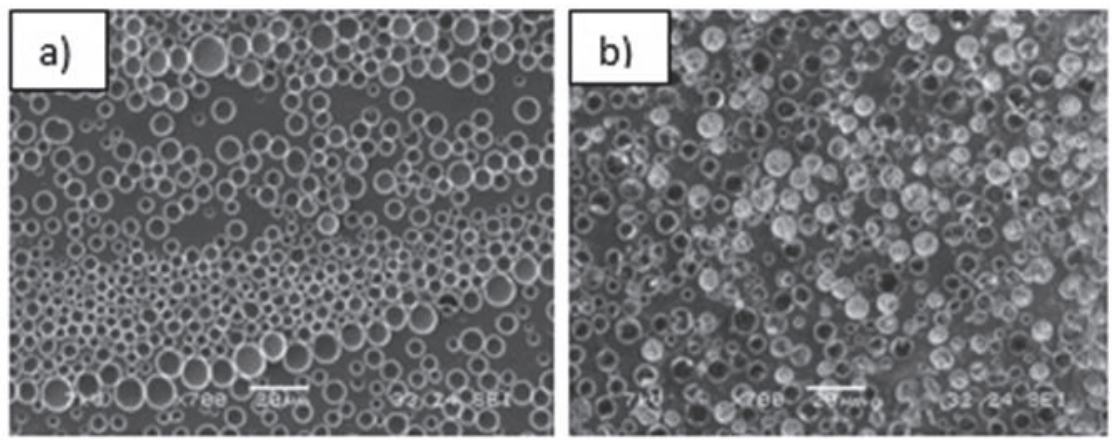

Fig. 4. The surface morphology for PLA-DSF-EPO-CEO films without treatment a) before and b) after 60 days of soil burial.
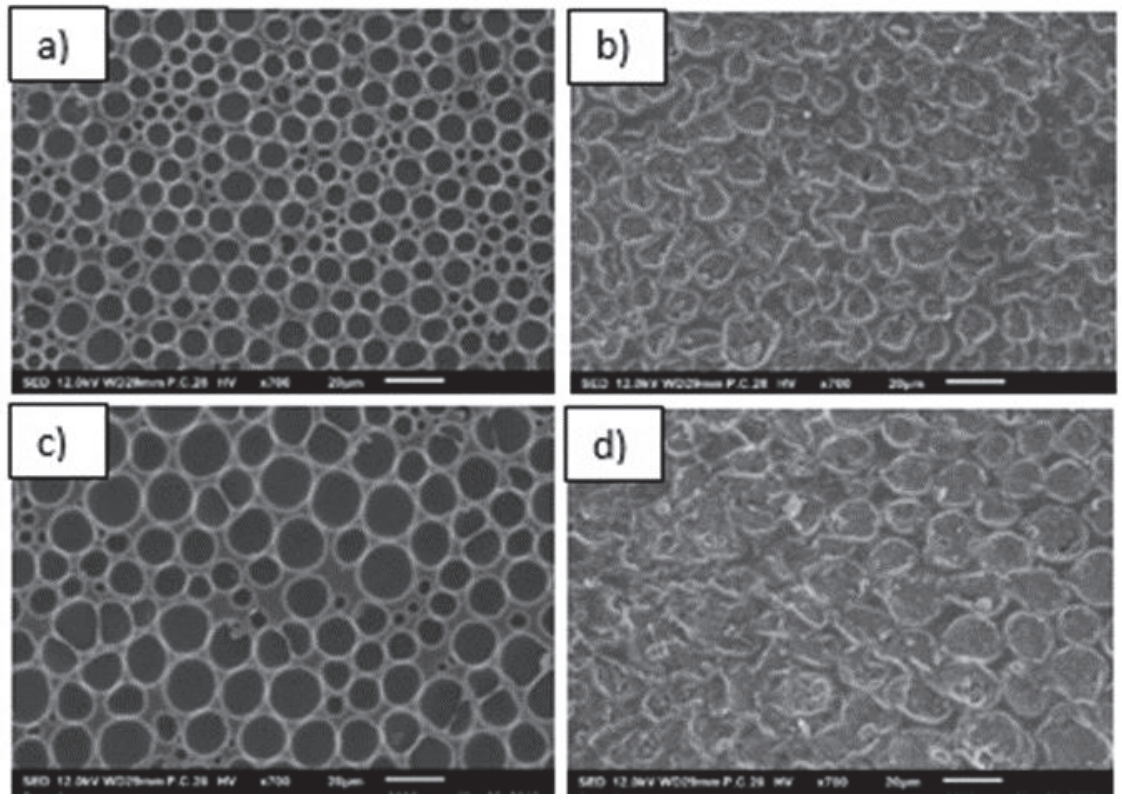

Fig. 5. The surface morphology for PLA-DSF-EPO-CEO films underwent $\mathrm{SCCO}_{2}$ treatment a) before degradation (condition 1), b) after degradation (condition 1), c) before degradation (condition 2) and d) after degradation (condition 2).

The influence of $\mathrm{SCCO}_{2}$ treatment with degradation time on the biocomposites was observed under SEM. More apparent physical changes had taken place within the surface of the biocomposites treated with $\mathrm{SCCO}_{2}$ compared to the samples without $\mathrm{SCCO}_{2}$. Based on the observation, Fig. 5(b) and (d) showed more ruptures than Fig. 4(b). The surface of the untreated films was less disrupted unlike the treated samples after Day 60. Such changes in the treated samples were signs of the degradation of the PLA biocomposite films. According to Fig. 5, before the soil burial test, a high porosity was observed on the surface of the biocomposite after the $\mathrm{SCCO}_{2}$ treatment. In contrast, after the burial in soil, all the films were rough and had numerous holes on the surface. Furthermore, the samples also physically changed. The weight loss results could be correlated with the SEM micrographs, as shown in Fig. 4 and 5. 


\subsection{Antimicrobial Analysis}

Antimicrobial activity was investigated in two steps. Firstly, the antimicrobial activity of the CEO was examined using the agar diffusion method. This preliminary study was carried out to evaluate the antimicrobial effect of pure CEO; the results are presented in Fig. 6 (a-b). In the second step, CEO was incorporated into the PLA film. The effect of the antimicrobial activity of CEO in the PLA biocomposites was studied using the agar diffusion method and it was then tested against selected microorganisms. There is no agreement on the standard procedures to evaluate the effectiveness of antimicrobial activities [14]. An antimicrobial test was conducted after the PLA biocomposites had been treated with $\mathrm{SCCO}_{2}$.

The antimicrobial activities of the untreated PLA biocomposite films incorporated with CEO against gram-positive (Staphylococcus aureus) and gram-negative (Escherichia coli) bacteria are shown in Fig. 6. Both bacteria represent the spoilage of the microorganism groups normally found in food products. The size of the inhibition zone around the disks determined the inhibitory activities of the specimen films [17]. Although the preliminary results of bacteria inhibition were satisfactory, showing that a complete inhibition of bacteria can be achieved by increasing the amount of CEO, the PLA biocomposites however became more brittle when the CEO content was increased. To overcome this problem, it was necessary to vary the content of the plasticizer. Nevertheless, this study focused only on the incorporation of $1 \mathrm{wt} \%$ of CEO.

The control samples without CEO negatively inhibit any of the tested bacteria, which resulted in no inhibition zones around the films. In Fig. $6(\mathrm{a}-\mathrm{b})$, all the films of the control samples were unable to stop the growth of the pathogens. In fact, bacteria colonies were formed on the agar. This result agreed with the findings by Ghasemlou et al. [28] on the plasticized corn starch films with essential oil. They reported that the control films negatively exhibited inhibition zone against the tested bacteria. This indicates that the main material used contained no antimicrobial agent, and therefore, the essential oil was incorporated into the polymer films. No clear zones appear show that the specimens were not inhibitory [17].

Fig. 6 (e-f) shows the inhibitory effect of films containing $1 \mathrm{wt} \%$ CEO against gram positive $(S$. aureus) and gram negative $(E$. coli) bacteria. All the films incorporated with CEO inhibited the growth of the two tested bacteria. The $1 \mathrm{wt} \%$ concentration of CEO resulted in a significant inhibition, with a diameter of $15.1 \pm 0.5 \mathrm{~mm}$ for $E$. coli and $12.5 \pm 0.5 \mathrm{~mm}$ for $S$. aureus. These results were significantly different from that of the control specimens. In Anuar et al. [1], the untreated PLA biocomposite film with $1 \mathrm{wt} \%$ of CEO showed an inhibition area of $15.05 \pm 0.5 \mathrm{~mm}$ for the Bacillus subtilis (gram-negative) and $12.8 \pm 0.5 \mathrm{~mm}$ for the $S$. aureus. There was a slight difference in the antimicrobial activity results between the treated and untreated samples. However, both samples still achieved the objective of inhibiting bacterial growth. This demonstrated that CEO had a strong antimicrobial activity towards both bacteria. The addition of $0.1 \mathrm{wt} \%$ of CEO to the PLA film is adequate to decrease the growth of the $S$. aureus [14]. The results of the current study were in agreement with those who also noticed a higher antimicrobial effect among biodegradable films incorporated with CEO [15]. It is important to note that the antimicrobial activity of the PLA film with CEO is based on preliminary studies that evaluated the antimicrobial activity of pure CEO, as in Fig. 6 (c-d). 


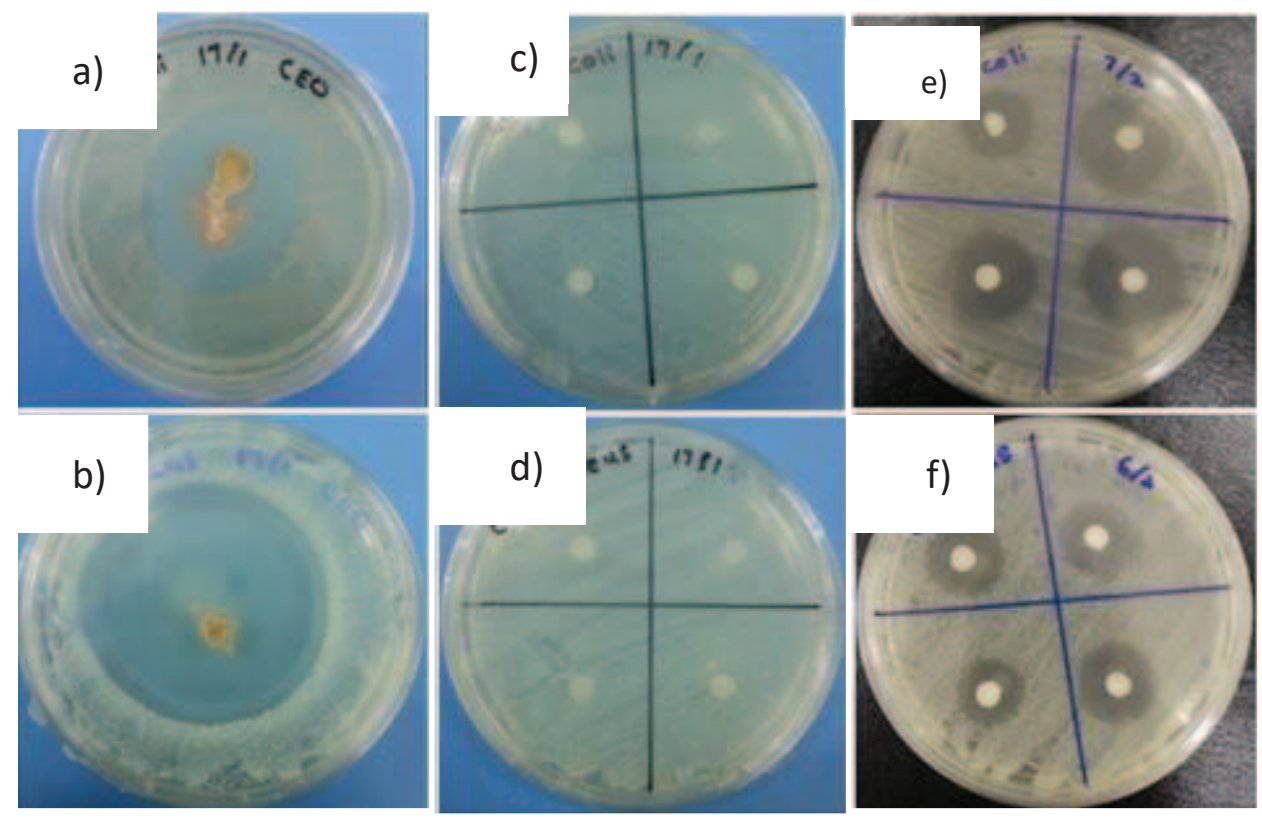

Fig. 6. The inhibition zone of a) control sample without $\mathrm{CEO}$ in E-coli, b) control sample without CEO in $S$. aureus, c) pure CEO in E. coli, d) pure CEO in $S$. aureus, e) sample incorporated CEO in E-coli and f) sample incorporated CEO in S. aureus.

Table 2 lists the results of the inhibitory effect of CEO incorporated into the bio-based polymer, which was lower than that of pure essential oil. The same outcome is observed as reported on polyvinyl alcohol (PVA)-cassava bagasse incorporated with essential oil [29,30]. According to Santos et al. [29] and Debiagi et al. [30], the processing surroundings caused a partial loss of the volatile components of the essential oil during the preparation of the biocomposite films. The gram-negative bacteria (E. coli) were more resistant than the gram-positive bacteria ( $S$. aureus) towards the antibacterial treatment. The lower antimicrobial activity against gram-negative bacteria $(E$. coli) affects the external lipopolysaccharide wall close to the peptidoglycan cell wall. This limits the diffusion of hydrophobic compounds through the lipopolysaccharide layer. On the other hand, grampositive bacteria $(S$. aureus) have a thick layer of peptidoglycan that may function as a preventive barrier against certain essential oil compounds [28].

Table 2: Antimicrobial activity of PLA biocomposite incorporated with CEO

Diameter of inhibitory zone (mm)

\begin{tabular}{cccc} 
Tested bacteria & Control & $\mathbf{1 ~ w t \% ~ C E O ~}$ & $\begin{array}{c}\text { PLA biocomposite incorporated } \\
\mathbf{1} \text { wt\% CEO }\end{array}$ \\
\cline { 2 - 4 } & $0 \pm 0$ & $35.3 \pm 0.5$ & $12.5 \pm 0.5$ \\
S. aureus & $0 \pm 0$ & $32.7 \pm 0.2$ & $15.1 \pm 0.5$ \\
\hline
\end{tabular}

The active compound, cinnamaldehyde, expressed a high antimicrobial activity against gram-positive and gram-negative bacteria. The antimicrobial efficiency of essential oils is related to the concentration and proportion of the phenolic compound [30]. It is believed that the amount of CEO that is added has a role in increasing the inhibition zone of the bacteria. Various researches have been carried out on essential oils incorporated into biocomposite films used in the food packaging industry. Phenolic compounds disintegrate 
https://doi.org/10.31436/iiumej.v21i1.1220

the external cell membrane and mitochondria of bacteria, allowing them to become permeable, and leading to leakage of the cell wall. From the gas chromatography (GC) data on CEO presented in Fig. 7, the presence of the main phenolic and terpenoid compounds effectively reduced the zone inhabited by the E. coli and $S$. aureus. The high content of cinnamaldehyde and $\alpha$-eugenol in CEO through a GC analysis as reported by Bongiovanni et al. [31]. CEO yielded good antibacterial activity compared to thyme and lemongrass oils, and better antibacterial activity than other essential oils like rosemary and oregano [32].

\subsection{Gas Chromatography}

About six different elements with varying retention times were detected via the gas chromatography (GC) analysis (Fig. 7). The contents of the elements identified in pure CEO are tabulated in Table 3. These elements were identified through a retention time and mass spectral library search. The relative amount of each constituent was calculated according to the GC peak area. As seen in Table 3, the antimicrobial components were characterised by a dominant concentration of cinnamaldehyde (46.615\%) and eugenol (16.345\%). Other main constituents included à-Pinene (2.901\%), 3-methyl-hepta-1,6-dien-3-ol (9.064\%), trans-á-Ocimene $(8.709 \%)$, and á-Phellandrene $(0.865 \%)$, which acted as antibacterial and antifungal elements but were less effective in inhibiting the bacteria. Most CEO components are phenolic in nature and are volatile, and also consist of trace levels of terpenes with antibacterial activity [33].

Table 3: Composition of element content in the pure cinnamon essential oil (CEO)

\begin{tabular}{|c|c|c|c|c|c|c|c|}
\hline $\begin{array}{c}\text { R.T. } \\
\text { (minutes) }\end{array}$ & $\begin{array}{c}\text { Name } \\
\text { Compound }\end{array}$ & Area \% & $\begin{array}{l}\text { Quant } \\
\text { S/N }\end{array}$ & Area & MW & Structure & $\begin{array}{c}\text { Molecular } \\
\text { Formula }\end{array}$ \\
\hline 6.84524 & à-Pinene & 2.9105 & 3.8659 & 294004 & 136 & & $\mathrm{C}_{10} \mathrm{H}_{16}$ \\
\hline 10.3362 & $\begin{array}{l}\text { 3-Methyl-hepta- } \\
\text { 1,6-dien-3-ol }\end{array}$ & 9.0646 & 4.5627 & 915667 & 126 & & $\mathrm{C}_{8} \mathrm{H}_{14} \mathrm{O}$ \\
\hline 15.4335 & trans-á-Ocimene & 8.7029 & 5.1193 & 879130 & 136 & & $\mathrm{C}_{10} \mathrm{H}_{16}$ \\
\hline 8.90751 & á-Phellandrene & 0.86546 & 2.5648 & 87425 & 136 & & $\mathrm{C}_{10} \mathrm{H}_{16}$ \\
\hline 14.9643 & Eugenol & 16.345 & 7.4453 & 1651138 & 164 & & $\mathrm{C}_{10} \mathrm{H}_{12} \mathrm{O}_{2}$ \\
\hline 12.9065 & $\begin{array}{l}\text { Cinnamaldehyde, } \\
\text { (E)- }\end{array}$ & 46.615 & 20.201 & 4708802 & 132 & & $\mathrm{C}_{9} \mathrm{H}_{8} \mathrm{O}$ \\
\hline
\end{tabular}

Cinnamaldehyde and eugenol combinations are already being used as disinfectants in hospitals, especially for medical devices [34]. The experimental test enabled the evaluation and comparison of antimicrobial activity against bacteria commonly found in food products. With these findings, it can be concluded that CEO is suitable and more effective against the tested bacteria since it presents a wider inhibition zone with a lower concentration. It was hypothesised that this result could be due to the presence of cinnamaldehyde as an active compound against both gram-positive and gram-negative bacteria. Furthermore, this finding also presented an important approach in developing active packaging with a lower 
concentration of active essential oil. Many studies on the antimicrobial activity of active films incorporated with other essential oils have indicated their potential for use in food packaging. As such, the effectiveness of antimicrobial films activated with CEO should be considered by the food packaging industry.

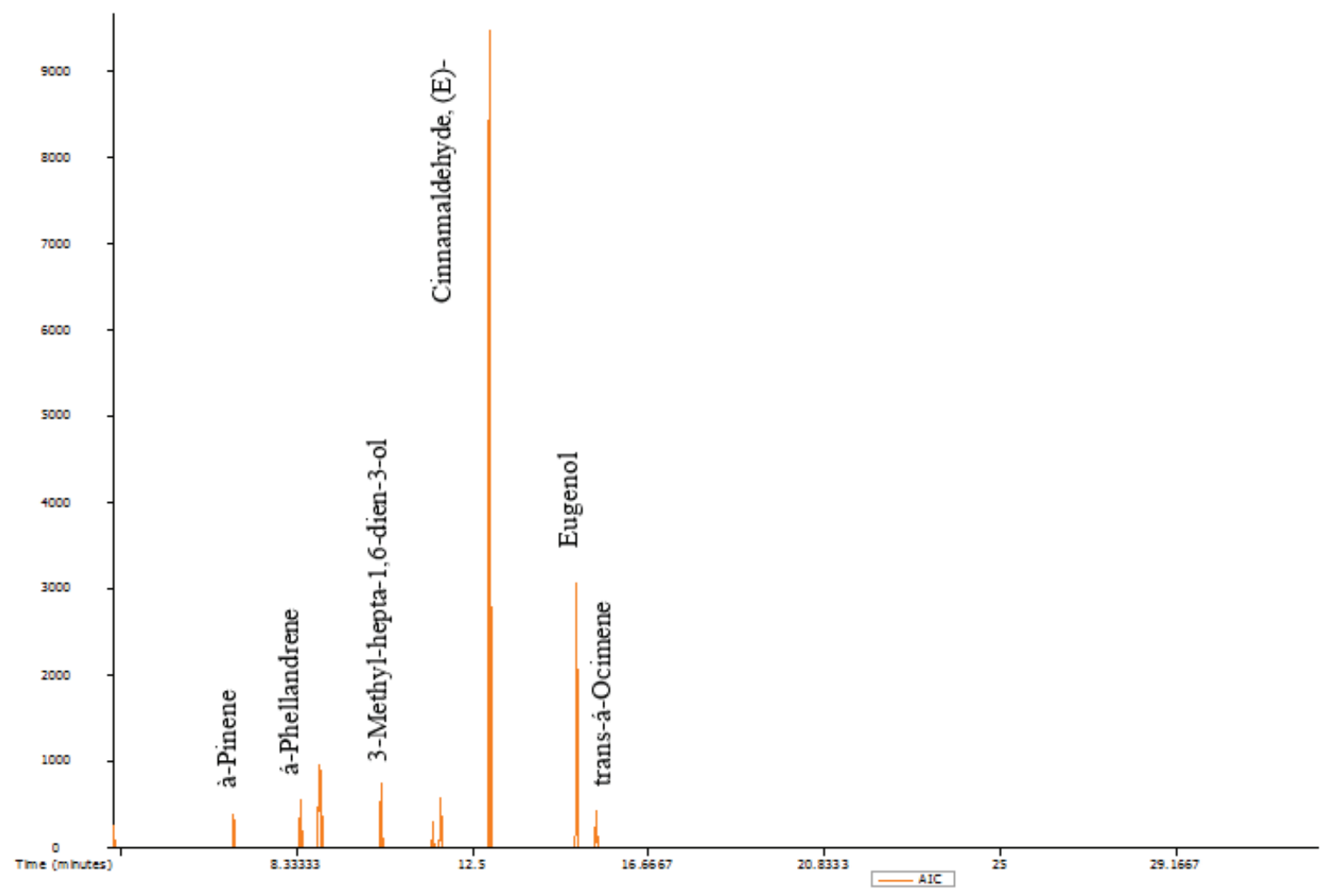

Fig. 7. Gas chromatography profile of cinnamon essential oil.

\section{CONCLUSION REMARKS}

The weight loss for PLA biocomposite was increased due to the presence of more porosity in the biocomposites. The water absorption evident that $\mathrm{SCCO}_{2}$ treatment aids to reduce the water uptake of PLA biocomposite due to plasticizing effect. The plasticizer decreased the moisture transfer between the food and packaging, thus improving the shelflife of packaged food. Only $1 \mathrm{wt} \%$ CEO has optimized the antimicrobial properties for active food packaging application. Besides that, the presence of aldehyde as a functional group in CEO was evident by using GC-MS/TOF. The use of CEO is very significant in this research as an antimicrobial agent for the biocomposites film. Based on the findings, $\mathrm{SCCO}_{2}$ could be an interesting alternative treatment in the food packaging industry as compared to the conventional method.

\section{ACKNOWLEDGEMENT}

The authors wish to thank the Ministry of Higher Education (MOE) for the funding provided through the Fundamental Research Grant Scheme (FRGS16-003-0502), Research Initiative Grant Scheme - Post-Doctoral Fellow (RPDF18-010-0010) from International Islamic University Malaysia (IIUM), Department of Science \& Technology (DST)-ASEAN-India 
IIUM Engineering Journal, Vol. 21, No. 1, 2020

Anuar et al.

https://doi.org/10.31436/iiumej.v21i1.1220

Research Training Fellowship (RTF/2019/000083) for the equipment and facilities provided in making these studies a success.

\section{REFERENCES}

[1] Anuar H, Nur Fatin Izzati B, Sharifah Nurul Inani SM, Siti Nur E'zzati MA, Siti Munirah Salimah AB, Ali FB, Manshor MR. (2017) Impregnation of cinnamon essential oil into plasticised polylactic acid biocomposite film for active food packaging. Journal of Packaging Technology and Research, 1(3): 149-157.

[2] Lithner D. (2011) Environmental and health hazards of chemicals in plastic polymers and products. PhD thesis. University of Gothenburg, Department of Plant and Environmental Sciences.

[3] Thothong S, Jarerat A, Sriroth K, Tantatherdtam R. (2013) Degradation of porous starch granules and poly (butylene adipate-co-terephthalate) (PBAT) blends: Soil burial and enzymatic tests. Advanced Materials Research, 651: 12-17.

[4] Nur Aimi MN, Anuar H, Manshor MR, Wan Nazri WB, Sapuan SM. (2014) Optimizing the parameter in durian skin fiber reinforced polypropylene composites by response surface methodology. Industrial Crops and Products, 54: 291-295.

[5] Yussuf AA, Massoumi I, Hassan A. (2010) Comparison of polylactic acid/kenaf and polylactic acid/rise husk composites: The influence of the natural fibres on the mechanical, thermal and biodegradability. Journal of Polymers and the Environment, 18(3): 422-429.

[6] Gunti R, Ratna Prasad AV, Gupta AVSSKS. (2016) Mechanical and degradation properties of natural fiber-reinforced PLA composites: Jute, sisal and elephant grass. Polymer Composites, 39(4): 1125-1136.

[7] Kumar R, Yakubu MK, Anandjiwala RDY. (2010) Biodegradation of flax fibre-reinforced polylactic acid. Express Polymer Letters, 4(7): 423-430.

[8] Wan Nazri WB, Ezdiani ZN, Romainor MM., Erma KS, Jurina J, Noor Fadzlina IZA. (2014)Effect of fibre loading on mechanical properties of durian skin fibre composite. Journal Tropical Agriculture and Food Science, 42(2): 169-174.

[9] Manshor MR, AnuarH, Nur Aimi NM, Ahmad Fitrie MI, Wan Nazri WB, Sapuan SM, ElShekeil YA, Wahid MU. (2014) Mechanical, thermal and morphological properties of durian skin fibre reinforced PLA biocomposites. Material and Design, 59: 279-286.

[10] Ali F, Awale Fakhruldin RJ, Anuar H. (2016) Plasticizing poly (lactic acid) using epoxidized palm oil (EPO) for environmental friendly packaging material. Malaysian Journal of Analytic Sciences, 20(5): 1153-1158.

[11] Silverajah VSG, Ibrahim NA, Yunus WM, Hassan HA, Woei CB. (2012) A comparative study on the mechanical, thermal and morphological characterization of poly (lactic acid)/epoxidized palm oil blend. International Journal of Molecular Sciences, 13: 5878-5898.

[12] Chieng BW, Ibrahim NA, Wan Md Zin WY, Hussein MZ. (2014) Epoxidized vegetable oils plasticized poly (lactic acid): Mechanical, thermal, and morphology properties. Journal Applied Polymer Science, 130: 4576-4580.

[13] Souza A, Dias AMA, Sousa HC, Tadini CC. (2013) Cassava starch composite films incorporated with cinnamon essential oil: Antimicrobial activity, microstructure, mechanical and barrier properties. LWT - Food Science and Technology, 54: 346-352.

[14] Qin Y, Yang J, Xue J. (2015) Characterization of antimicrobial poly (lactic acid)/ poly (trimethylene carbonate) films with cinnamaldehyde. Journal of Material Science, 50(3): $1150-1158$.

[15] Erdohan ZÖ, BelgizarC, Turhan KNB. (2013) Characterization of antimicrobial polylactic acid-based films. Journal of Food Engineering, 119(2): 308-315.

[16] Vazirian MA, Alehabib S, Hossein J, Mohammad RF, Toosi AN, Mahnaz K. (2015) Antimicrobial effect of cinnamon (Cinnamomum verum J. Presl) bark essential oil in creamfilled cakes and pastries. Research Journal of Pharmacognosy, 2(4): 11-16.

[17] Wu J, Sun X, Guo X, Ge S, Zhang Q. (2017) Physicochemical properties, antimicrobial activity and oil release of fish gelatin films incorporated with cinnamon essential oil. Aquaculture and Fisheries, 2(4): 185-192. 
https://doi.org/10.31436/iiumej.v21i1.1220

[18] Milovanovic S, Kuska R, Skoric-Lucic M, Kalagasidis-Krusic M, Frerich S, Zizovic, I, Ivanovic J. (2016) Swelling kinetics and impregnation of PLA with thymol under supercritical CO2 conditions. Tehnika, 71(1): 16-20.

[19] Patpen P, Russly AR, Rosnita AT, Khalina A. (2015) Mechanical properties and water absorption behaviour of durian rind cellulose reinforced poly (lactic acid) biocomposites. International Journal on Advanced Science Engineering Information Technology, 5(5): 343348.

[20] González A, Alvarez I, Cecilia I. (2013) Soy protein - Poly (lactic acid) bilayer films as biodegradable material for active food packaging. Food Hydrocolloids, 33(2): 289-296.

[21] Souza A, Goto GEO, Mainardi JA, Coelho ACV,Tadini CC. (2014) Impregnation of cinnamaldehyde into cassava starch biocomposite films using supercritical fluid technology for the development of food active packaging. Carbohydrate Polymers, 102: 830-837.

[22] Aranda-GarciaFJ, González-Núñez R, Jasso-Gastinel CF, Mendizábal E. (2015) Water absorption and thermomechanical characterization of extruded starch/poly (lactic acid)/ agave bagasse fibre bioplastic composites. International Journal of Polymer Sciences, 2015: 1-7.

[23] Emad AJA, Wan Md. Zain WY, Nor Azowa I, Mohd Zaki AR. (2010) Properties of epoxidized palm oil plasticized polylactic acid. Journal Material Science, 45: 1942-1946.

[24] Seniha GF, Yagci Y, TuncerEAY. (2006) Polymers from Triglyceride Oils. Progress in Polymer Science, 31: 633-670.

[25] Amer ZJA, Saeed AQ. (2015) Soil burial degradation of polypropylene/ starch blend. International Journal of Technical Research and Applications, 3(1): 91-96.

[26] Weng YX, Jin YJ, Meng QY, Wang L, Zhang M, Wang YZ. (2013) Biodegradation behaviour of poly (butylene adipate-co-terephthalate) (PBAT), poly (lactic acid) (PLA), and their blend under soil conditions. Polymer Testing, 32(5): 918-926.

[27] Lardjane N, Belhaneche BN. (2009) Migration of additives in simulated landfills and soil burial degradation of plasticized PVC. Journal of Applied Polymer Science, 111(1): 525-531.

[28] Ghasemlou M, Aliheidari N, Fahmi R, Shojaee-Aliabadi S, Keshavarz B, Cran MJ, Khaksar R. (2013) Physical, mechanical and barrier properties of corn starch films incorporated with plant essential oils. Carbohydrate Polymers, 98(1): 117-1126.

[29] Santos SF, Novales MG. (2012) Essential Oils from Aromatic Herbs as Antimicrobial Agents. Current Opinion in Biotechnology, 23: 136-141.

[30] Debiagi F, Kobayashi, Renata KT, NakazatoGP, Luciano A, Mali S. (2014) Biodegradable active packaging based on cassava bagasse polyvinyl alcohol and essential oils. Industrial Crops and Products, 52: 664-670.

[31] Bongiovanni V, Colombo M, Laura C, Andrea T, Daniela C. (2017) Determining odour-active compounds in a commercial sample of cinnamomun cassia essential oil using GC-MS and GC-O. Journal of Chromatography \& Separation Techniques, 8(1): 1-7.

[32] Gende L, Floris I, Fritz R, Eguaras M. (2008) Antimicrobial activity of cinnamon (Cinnamon zeylanicum) essential oil and its main components against Paenibacillus larvae from Argentine. B. Insectol, 61(1): 1-4.

[33] Adinew B. (2014) GC-MS and FT-IR analysis of constituents of essential oil from cinnamon bark growing in South-west of Ethiopia. International Journal of Herbal Medicine, 1(6): 2231.

[34] Goni P, Lopez P, Sanchez C, Gomez LR, Beceril R, Nerin C. (2009) Antimicrobial activity in the vapour phase of a combination of cinnamon and clove essential oils. Food Chemistry, 116: 982-989. 